\title{
NEXT GENERATION SOLUTIONS FOR TVS, OTTS AND VODS WITH IP VIA SATELLITE
} Chair: JOSÉ RAIMUNDO CRISTÓVAM NASCIMENTO - Diretor Técnico na UNISAT / Representante do GVF - Global VSAT Forum no Brasil e Vice-Diretor da SET Sudeste In the new context of satellite broadcasts, with the increasing use of IP Video and Audio IP and the beginning of change of concept of rent of $\mathrm{MHz}$ to render services in Mbit / s, Mbytes and in other possible business models and conditions Contractors, the main satellite operators will present their state-of-the-art solutions and technologies, applications, services and associated differentials for use by different companies in the audiovisual value chain, including the TV, OTT and VOD areas. The goal is that the audience has access to really new information.

- NEW APPLICATIONS IN SATELLITE DTH SYSTEMS: VOD, MULTISCREENS, HYBRID SYSTEMS Speaker: Jurandir Pitsch - Vice President Sales - SES

The presentation will address new applications complementing traditional DTH systems. The use of HEVC compression technology will enable the transmission of more advanced DTH systems, including $4 \mathrm{~K}$ UHD channels, multi-screen systems for users to watch on mobile devices in their homes, VOD systems, catch up TV and many others.

- INNOVATIVE SOLUTIONS FOR SATELLITE IP BROADCASTS Speaker: Ricardo Calderón - Sales Director - Eutelsat do Brasil

With its extensive and flexible fleet of 39 satellites covering virtually the entire globe, Eutelsat also develops IP transmission solutions to boost the use of satellites. SmartBEAM, a multi-screen content distribution solution and SmartLNB, efficient connection for Machine-to-Machine (M2M) applications are 2 examples of developments in this area. 
- MYTHS AND FACTS OF TV CONSUMPTION

Speaker: Edio Gomes - Technical and Operational Director of Hispamar Satellites

We'll look at some myths and facts about how today's consumers watch TV, and some market data.

- MPTS VIA SATELLITE

Speaker: William John Hemmings - Romantis Sales Director for Brasil

We will present the project of Romantis Brazil on multiple Sports Channels traveling through Satellite to the ERBs ( radio base stations) of the Telecom Operator where they will travel to the end user through the LTE Broadcasting network that is adequate and designed for Video traffic with very low latency.

- TELESAT LEO CONSTELLATION

Speaker: Mauro Wajnberg - General Director of Telesat Brasil

Description of the low-orbit satellite system to be launched by Telesat.

- INNOVATIONS OF CONTRIBUTION WITH IP VIDEO IN MULTINETWORKS

Speaker: Marcio Brasil - Managing Sales Director of the INTELSAT Office in Brazil

Do you want to simplify IP Video operations and get robust transmission of video? Learn more about cell operations technology, satellites, and the latest innovations for the best IP Media class platforms.

- SATELLITE: TRENDS AND NEW APPLICATIONS Speaker: Geraldo Cesar de Oliveira - Product Manager - Star One Space Segment

This is a very important moment for Satellite Operators. Several alternative transmission media, applications and technologies have emerged, and for this particular industry that takes around three years to specify their products and keep them alive for a period of 15 to 18 ,it is mandatory a correct evaluation of the New market trends (DTH, VOD, OTT, IPTV, HDTV, IOT, WI-Fi On Board ... etc).

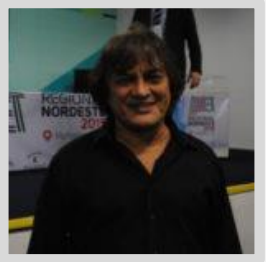

JOSÉ RAIMUNDO CRISTÓVAM NASCIMENTO - Diretor Técnico na UNISAT I

Representante do GVF - Global VSAT Forum no Brasil e Vice-Diretor da SET Sudeste

He has been active in satellite communications since 1983, having headed up project teams on several occasions. Associate Director and one of the founders of UNISAT in 1990. He is the company's technical director and a senior consultant to Brazilian and international companies. Before founding UNISAT, he worked at NEC, TELEBAHIA and EMBRATEL in the National and International areas, in communications via the Brasilsat and Intelsat satellites, having been a 
member of the Domestic Satellite Communications Department, known as SAT.He is an Operations Engineer in Electronics, from the School of Engineering of the UGF, a Graduate Degree from the UFF in Telecommunications, specialization courses in Japan (NEC, NTT and Anritsu) and in the USA (TCB - Thomson)..

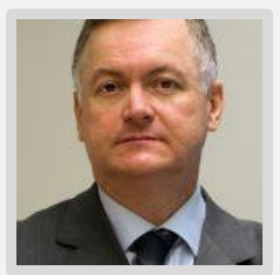

\section{Jurandir Pitsch - Vice President Sales - SES}

Jurandir Pitsch is the Vice President of Sales and Business Development for the Latin America region, at SES. He is a telecom engineer, with more than 35 years acting in satellites business.

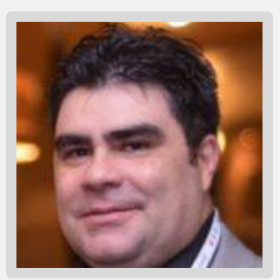

\section{Ricardo Calderón - Sales Director - Eutelsat do Brasil}

Graduated in electronic engineering from Escola de Engenharia Mauá, he has 29 years of experience in communications by satellite, Broadcast and PayTV. He has been the Director of Sales at Eutelsat in Brasil since 2015.

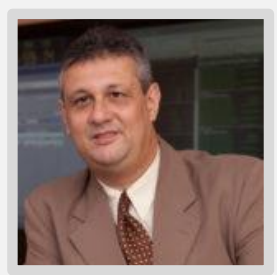

\section{Edio Gomes - Technical and Operational Director of Hispamar Satellites}

With over 38 years of experience in satellite communications and training in Telecommunications, IT and Business Administration, Edio Gomes occupies since 2004 the position of Chief Technical and Operational Hispamar Satellites. Previously, Edio has worked in various positions at Globalstar Brazil, Intelsat (in Washington, DC) and Embratel. Edio also holds an Executive MBA from COPPEAD.

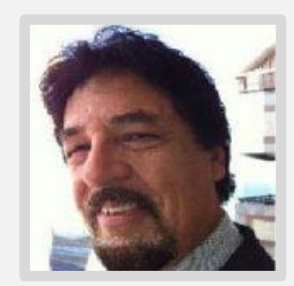

\section{William John Hemmings - Romantis Sales Director for Brasil}

He worked as Director of Satellite Operators Loral Skynet and TELESAT and is currently Director of Romantis Brazil which is the representative before ANATEL of the Operator Satellite RSCC, which will be present in booth at SET EXPO 2017 with information on the satellite Express AM8 and How to bring TV Contribution in a single jump in C band of the 2018 FIFA World Cup in Russia.

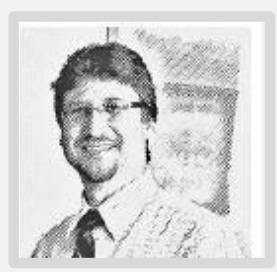

\section{Mauro Wajnberg - General Director of Telesat Brasil}

Mauro Wajnberg has been working in the satellite communications industry for more than 25 years. He is currently serving as the Officer for Telesat Brazil, a subsidiary of Telesat Canada, the fourth largest global satellite operator. Prior to Telesat, Mr. Wajnberg was Director of Marketing and Products at Embratel's satellite operator Star One. Previously, Mr. Wajnberg held several positions in major telecom companies focusing on services for the corporate market, including the deployment of the first VSAT networks in Brazil.Mr. Wajnberg holds an Electronic Engineering degree from the Military Institute of Engineering, Brazil, and an Executive MBA from Fundacao Getulio Vargas (FGV), Brazil.In addition to his activities in Telesat Brazil, Mauro Wajnberg is also the President of the Chapter Brazil of SSPI, the Society of Satellite Professionals International. 


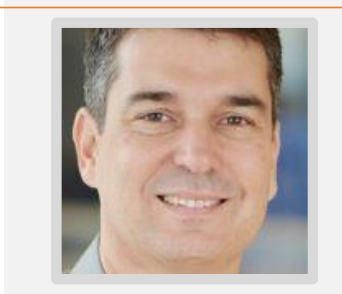

\section{Marcio Brasil - Managing Sales Director of the INTELSAT Office in Brazil}

Marcio Brasil began to act as Managing Sales Director of Intelsat of the Office of Brazil in August of 2010. Since July of 2015, he is Managing Sales Director of the Sales Office of Brazil. He is responsible for managing Intelsat's sales activities in Brazil. Before that position, Mr. Marcio Brasil worked for more than 20 years in the Telecommunications and Satellite Markets, having worked in management positions in Operations, Engineering, Project Management, Business Development and Sales. Mr. Brazil obtained a BSc. In Electrical Engineering / Telecommunications at PUCPontifical Catholic University of Rio de Janeiro, MSc. In Electronic Engineering / Telecommunications at Universidade Mackenzie in São Paulo and an MBA in Business Administration from Fundação Getúlio Vargas in Rio de Janeiro.

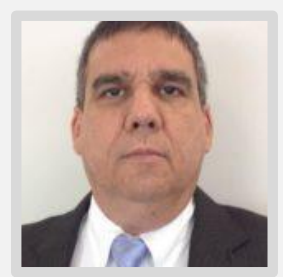

\section{Geraldo Cesar de Oliveira - Product Manager - Star One Space Segment}

Graduated in Electronic Engineering in 1985, in Telecommunications Engineering in 1986, Master in Telecommunications Systems Engineering at Pontificia Universidade Católica do Rio de Janeiro (PUC - CETUC-RJ) and MBA in Executive Marketing at the Brazilian Institute of Capital Markets $\mathrm{RJ})$. 